\title{
Proficiency Test Policy and Plan for State Weights \& Measures Laboratories (2018 Ed)
}

Georgia L. Harris

L. F. Eason Ken Fraley

Kelleen Larson

This publication is available free of charge from:

https://doi.org/10.6028/NIST.IR.7082-2018 


\section{Proficiency Test Policy and Plan for State Weights \& Measures Laboratories (2018 Ed)}

Georgia L. Harris Office of Weights and Measures Physical Measurement Laboratory

L. F. Eason (retired North Carolina Metrology Laboratory, NVLAP Assessor)

Ken Fraley (retired Oklahoma Bureau of Standards, NVLAP Assessor)

Kelleen Larson (retired Arizona Weights and Measures Laboratory, NVLAP Assessor)

This publication is available free of charge from: https://doi.org/10.6028/NIST.IR.7082-2018

February 2018

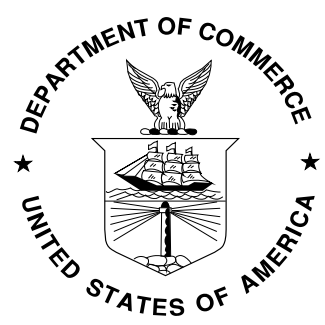

U.S. Department of Commerce Wilbur L. Ross, Jr., Secretary 


\section{Table of Contents}

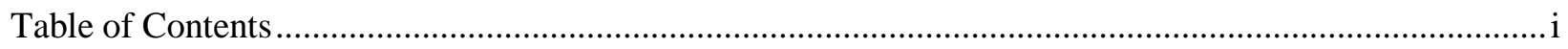

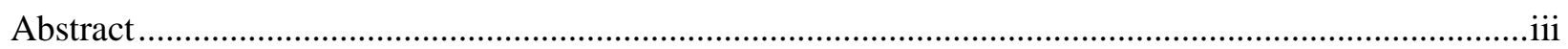

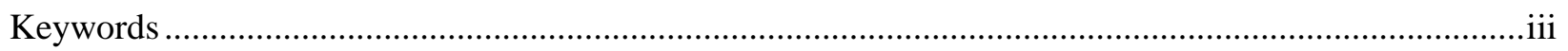

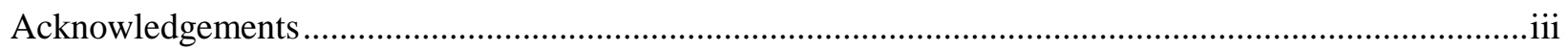

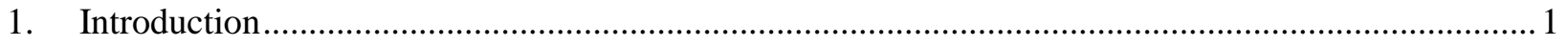

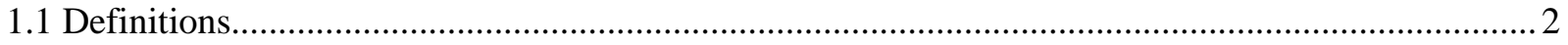

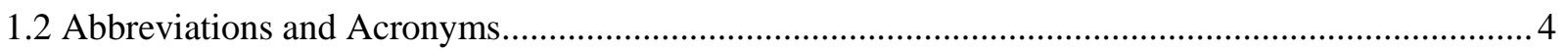

Table 1. Abbreviations and Acronyms Used in this Publication. ........................................................... 4

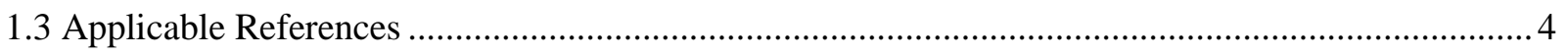

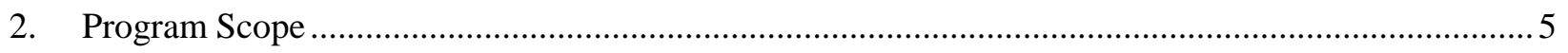

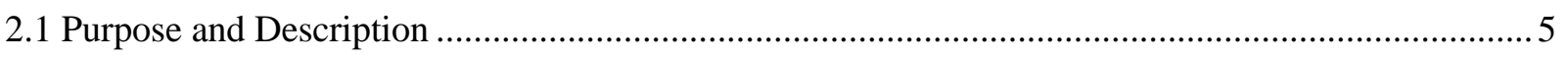

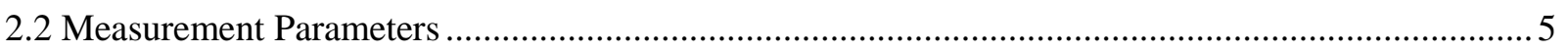

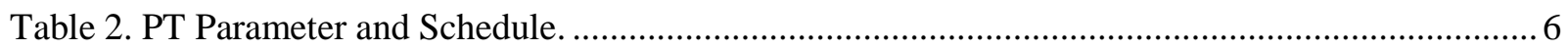

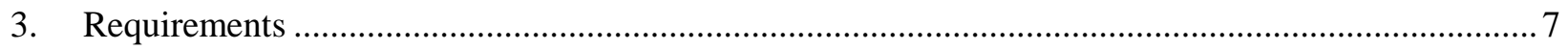

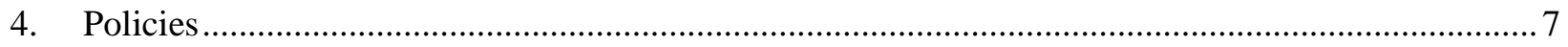

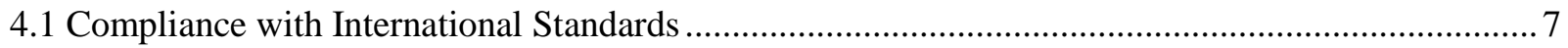

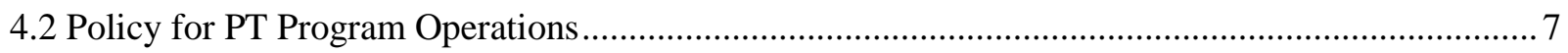

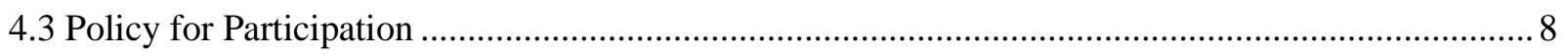

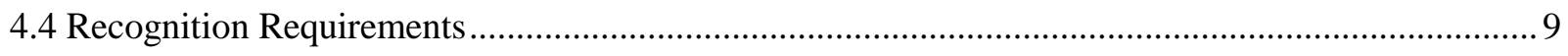

4.5 Laboratory and Individual Metrologist Competence Status ....................................................... 9

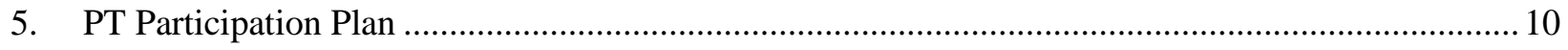

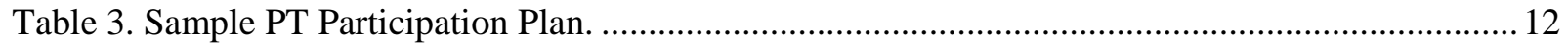




\section{Abstract}

This publication provides the policies and plans for the PT Program of the NIST Office of Weights and Measures. This Office of Weights and Measures (OWM) Proficiency Testing (PT) policy and plan has been updated to ensure compliance with the latest applicable documentary standards and policies of the International Laboratory Accreditation Cooperation (ILAC).

The PT program has been in place since the early 1980s as a core part of the support to State weights and measures laboratories through regional measurement assurance programs. Original activities were conducted as "round robins" in support of ongoing measurement assurance activities related to support for State laws with requirements for metrological traceability to national and international standards.

Kelleen Larson, L. F. Eason, and Ken Fraley in collaboration with NIST OWM personnel at the 2012 PT Workshop, Boulder, Colorado, proposed significant updates to this publication, which form the foundation for the 2018 update. Reviews by the participants listed below significantly contributed to the development of this policy and plan. The initial 2004 edition was developed under contract with Jeff C. Gust.

\section{Keywords}

Accreditation, calibration, interlaboratory comparison, proficiency testing, recognition.

\section{Acknowledgements}

The following individuals participated in the 2018 review:

- Val Miller, NIST / OWM

- Tim Osmer, NIST / OWM

- Elizabeth Gentry, NIST / OWM

- Titilayo Shodiya, NIST / National Voluntary Laboratory Accreditation Program (NVLAP)

The following individuals contributed to the review resulting from the 2012 PT Workshop Review:

- Georgia Harris, NIST / OWM

- Kelleen Larson, Consultant

- L. F. Eason, rEason Metrology Consulting, LLC

- Ken Fraley, Consultant

- Val Miller, NIST / OWM

- Elizabeth Gentry, NIST / OWM

- Aaron Aydelotte, Oregon Metrology Laboratory

- Barbara Belzer, NIST / National Voluntary Laboratory Accreditation Program (NVLAP) 


\section{Proficiency Test Policy and Plan for State Weights \& Measures Laboratories}

\section{Introduction}

This Office of Weights and Measures (OWM) proficiency testing (PT) policy and plan is designed to assist the National Institute of Standards and Technology (NIST) and the State weights and measures laboratories and Regional Measurement Assurance Program (RMAP) groups in identifying the minimum level of proficiency testing needed on an ongoing basis to comply with international expectations as described in the PT Requirements section of this document.

In addition to State weights and measures laboratory participation, the OWM PT Program includes participation (when applicable) by the U.S. Department of Agriculture, Grain Inspection and Packers and Stockyards master track scale, Los Angeles County Weights and Measures, the District of Columbia, and the U.S. territories of Puerto Rico and the U.S. Virgin Islands. In realizing compliance to this policy, some of the PTs will be conducted through the RMAP groups and others will have to be coordinated on a national basis.

The terms Interlaboratory Comparison (ILC) and Proficiency Test(PT) are often used interchangeably. However, PTs are a subset of ILCs that may be used for other purposes. Hereafter in this document, the term PT will be used to refer to all PTs and ILCs for simplicity, recognizing that some ILCs are not designed to be PTs. This policy and plan addresses these different coordination needs. The OWM PT Program serves purposes beyond demonstrating proficiency for recognition and accreditation activities. Proficiency testing involves the use of interlaboratory comparisons for the determination of laboratory performance for:

a) Evaluating laboratory performance of specific measurement scope capabilities and monitoring continuing performance;

b) Identifying problems and initiating corrective action. Example causes may include inadequate measurement procedures, ineffectiveness of staff training and supervision, or needed standards and equipment recalibration;

c) Establishing the effectiveness and comparability of measurement methods (e.g., method validation);

d) Evaluating method performance characteristics (e.g., method validation).

e) Providing additional confidence to laboratory customers;

f) Identifying of differences among laboratories; and

g) Educating participating laboratories based on comparison outcomes. For example, Laboratory Auditing Program (LAP) problems are assigned to the state weights and measures staff after OWM training and prior to OWM recognition as approved signatories for measurements); and

h) Validating uncertainty claims.

While OWM does not operate a formal accreditation program, OWM is responsible for 
implementing a weights and measures laboratory recognition program according to NIST Handbook 143, Program Handbook. OWM issues Certificates of Metrological Traceability that detail defined measurement scopes to support legal metrology measurements that underpin U.S. trade and commerce. This policy and plan is consistent with international policies set forth by the International Laboratory Accreditation Cooperation (ILAC) as of 2018. It also supplements the PT requirements in NIST Handbook 143 and ISO/IEC 17025:2017.

As part of the State Laboratory Recognition Program (NIST Handbook 143), OWM is responsible for the Regional Measurement Assurance Programs (RMAPs). Metrologists from State legal metrology laboratories within six regions are required to attend annual training and participate in proficiency testing in planned measurement areas aligned with their OWM recognition measurement scope. State metrology laboratories may also seek accreditation from ILAC recognized accreditation bodies. RMAP PT results may be used to meet both recognition and accreditation requirements.

The six regions are the:

1) Northeastern Measurement Assurance Program (NEMAP);

2) Southeastern Measurement Assurance Program (SEMAP);

3) Southwestern Assurance Program (SWAP);

4) Mid-America Measurement Assurance Program (MidMAP);

5) Western Regional Assurance Program (WRAP); and

6) Caribbean Measurement Assurance Program (CaMAP)

Most PTs are coordinated by technical experts through the regional groups according to a regional schedule. Some PTs are coordinated by NIST personnel, regional experts, or NIST OWM approved PT providers.

OWM policies and procedures are aligned with the most recent ILAC documents and ensures that formal PT planning and follow-up continues to be implemented.

In this document, the following verbal forms are used:

- "Shall” indicates a requirement;

- "Should" indicates a recommendation;

- "May” indicates a permission; and

- “Can” indicates a possibility or a capability.

\subsection{Definitions}

For the purposes of this document, the terms and definitions in the International Vocabulary of Metrology (VIM) and the following apply in this document.

Accreditation: A formal process of determining the technical competence of a laboratory to carry out specific types of testing, measurement and calibration. It provides formal acknowledgement that the laboratory is competent, impartial and independent. Regular evaluation occurs to ensure continued compliance with requirements and to check that standards of operation are being maintained. 
Accuracy Class: A class of measuring instruments or measuring systems that meet stated metrological requirements that are intended to keep measurement errors or instrumental measurement uncertainties within specified limits under specified operating conditions.

Calibration: A set of operations which establish, under specified conditions, in a first step, establishes the relationship between values with measurement uncertainties provide by measurement standards and corresponding indications with associated measurement uncertainties and, in a second step, uses this information to establish a relation for obtaining a measurement result from an indication.

Calibration and Measurement Capability (CMC): A CMC is a calibration and measurement capability available to customers under normal conditions: (a) as published in the BIPM key comparison database (KCDB) of the CIPM Mutual Recognition Arrangement (MRA); or (b) as described in the laboratory's scope of accreditation granted by a signatory to the ILAC Arrangement.

Certificate of Metrological Traceability: Document issued by OWM to a participating state legal metrology laboratory that has been granted recognition according to NIST HB 143 requirements and is always issued with a Measurement Scope.

Corrective Action: An action taken to eliminate the causes of an existing nonconformity or other undesirable situation to prevent recurrence.

Interlaboratory Comparison: The organization, performance and evaluation of measurements or tests on the same or similar items by two or more laboratories or inspection bodies accordance with predetermined conditions.

Intralaboratory Comparison: The organization, performance, and evaluation of measurements or tests on the same or similar items within the same laboratory in accordance with predetermined schedule.

Laboratory: An organization that performs tests, calibrations, and/or sampling associated with subsequent testing or calibration. When a laboratory is part of an organization that carries out activities additional to calibration and testing, the term "laboratory" refers only to those parts of that organization that are involved in the calibration and testing process. A laboratory's activities may be carried out at a permanent location, temporary, or remote location. A laboratory may be further defined as being a physical entity that is, a testing or calibration facility that is separate and apart physically from any other laboratory whether sharing common ownership, management, or management systems with any other laboratory.

Measurement Procedure: A detailed description of a measurement according to one or more measurement principles and to a given measurement method, based on a measurement model and including any calculation to obtain a measurement result.

Measurement Scope: A range of approved measurements issued by OWM to a participating state legal metrology laboratory that has been granted OWM recognition. The measurement scope is found on the Certificate of Metrological Traceability and details calibration services for which the laboratory is recognized. See also: Calibration and Measurement Capability. 
Metrological Traceability: The property of a measurement result whereby the result can be related to a reference through a documented unbroken chain of calibrations, each contributing to the measurement uncertainty.

Participant: Laboratory, organization or individual metrologist that receives proficiency test artifacts, follows all planned instructions, tasks and timelines, and submits the measurement results for review by the proficiency testing provider.

Proficiency Test: The determination of the calibration or testing performance of a laboratory or the testing performance of an inspection body against pre-established criteria by means of interlaboratory comparison.

State Laboratory Program: A NIST OWM Program that provides guidance, technical support, and assistance to state legal metrology laboratories to ensure accurate and traceable measurements are made within each participating jurisdiction.

\subsection{Abbreviations and Acronyms}

Table 1. Abbreviations and Acronyms Used in this Publication.

\begin{tabular}{|l|l||}
\hline $\begin{array}{c}\text { Abbreviation or } \\
\text { Acronym }\end{array}$ & \multicolumn{1}{c|}{ Description } \\
\hline \hline AB & Accreditation Body \\
\hline $\begin{array}{l}\text { IACET } \\
\text { IEC }\end{array}$ & $\begin{array}{l}\text { International Association for Continuing Education and Training } \\
\text { International Electrotechnical Commission }\end{array}$ \\
\hline ILAC & International Laboratory Accreditation Cooperation \\
\hline ILC & Interlaboratory Comparison \\
\hline ISO & International Organization for Standardization \\
\hline MRA & Mutual Recognition Arrangement \\
\hline NIST & National Institute of Standards and Technology \\
\hline NISTIR & NIST Interagency or Internal Report \\
\hline NVLAP & National Voluntary Laboratory Accreditation Program \\
\hline OWM & Office of Weights and Measures \\
\hline PT & Proficiency Test \\
\hline RMAP & Regional Measurement Assurance Program \\
\hline
\end{tabular}

\subsection{Applicable References}

The following documents are referred to in the text in such a way that some or all of their content constitutes requirements of this document. For dated references, only the edition cited applies. For undated references, the latest edition of the referenced documents (including any amendments) applies.

- ISO/IEC Guide 98-1:2009, Guide to the Expression of Uncertainty in Measurement (GUM), (aka JCGM 100:2008).

- ISO/IEC Guide 99:2007, International Vocabulary of Metrology - Basic and General Concepts and Associated Terms (VIM), 3rd edition, 2008 version with minor corrections (Confirmed 2015), (aka JCGM 200:2012).

- ISO/IEC 17011:2017, Conformity Assessment -- Requirements for Accreditation Bodies 
Accrediting Conformity Assessment Bodies.

- ISO/IEC 17025:2017, General Requirements for the Competence of Testing and Calibration Laboratories.

- ISO/IEC 17043:2010, Conformity Assessment - General Requirements for Proficiency Testing.

- ILAC P9:06/2014, ILAC Policy for Participation in Proficiency Testing Activities.

- ILAC-P14:01/2014, ILAC Policy for Uncertainty in Calibration.

- NIST Handbook 143:2018, State Weights and Measures Laboratories, Program Handbook, 6th Edition.

- $\quad$ NIST Handbook 150:2016, NVLAP Procedures and General Requirements.

- $\quad$ NIST Handbook 150-2:2016, NVLAP Calibration Laboratories.

- $\quad$ NISTIR 7214, Office of Weights and Measures, Quality Manual for Proficiency Testing and Interlaboratory Comparisons.

\section{Program Scope}

\subsection{Purpose and Description}

The OWM PT Program is administered to support State metrological traceability legal requirements and operated through a national infrastructure of regions, the Regional Measurement Assurance Program (RMAP). Participation in all OWM PTs is limited to State Weights and Measures laboratories, where personnel have demonstrated adequate on-the-job training and success completion of applicable OWM training seminars. OWM PT Program activities are limited to the U.S. states and territories.

Non-weights and measures laboratory participants within the RMAPs are eligible to participate in the OWM PT Program only when personnel have successfully completed training requirements (at suitable and NIST-approved levels) and participate in annual RMAP training on an ongoing basis.

OWM personnel are responsible for evaluating PT Program participants, including the approval or denial of participation before a PT commences.

\subsection{Measurement Parameters}

NIST HB 143 defines recognition measurement scope parameters (calibration and measurement capabilities). Successful PT completion in one measurement area, range, or parameter does not necessarily indicate that a laboratory will be successful in other areas. PT requirements shall be met for all measurement parameters where a laboratory personnel serves as an approved signatory because each scope area is based on a unique system of resources, including facilities, standards, and equipment. 
Table 2. PT Parameter and Schedule.

\begin{tabular}{|c|c|c|c|c|c|}
\hline $\begin{array}{l}\text { Measurement } \\
\text { Parameter }\end{array}$ & $\begin{array}{c}\text { Typical } \\
\text { Calibration } \\
\text { Standard }\end{array}$ & $\begin{array}{c}\text { Typical } \\
\text { Recognition } \\
\text { Scope Range }\end{array}$ & $\begin{array}{l}\text { Typical } \\
\text { PT Range }\end{array}$ & $\begin{array}{c}\text { Minimum } \\
\text { Recommended } \\
\text { Participation } \\
\text { per Parameter } \\
\text { (Alternating } \\
\text { Ranges) }\end{array}$ & Frequency \\
\hline \multirow{2}{*}{$\begin{array}{c}\text { Mass } \\
\text { Echelon } \mathrm{I}^{\mathrm{a}, \mathrm{b}}\end{array}$} & \multirow{2}{*}{$\begin{array}{c}\text { Mass } \\
\text { Standard }\end{array}$} & \multirow{2}{*}{$\begin{array}{c}30 \mathrm{~kg} \text { to } 1 \mathrm{mg} \\
50 \mathrm{lb} \text { to } 0.001 \mathrm{lb} \\
8 \mathrm{oz} \text { to } 0.03125 \mathrm{oz}\end{array}$} & $20 \mathrm{~kg}$ to $1 \mathrm{~kg}$ & 2 year & 4 year \\
\hline & & & $1 \mathrm{~kg}$ to $1 \mathrm{mg}$ & & 4 year \\
\hline \multirow{3}{*}{$\begin{array}{c}\text { Mass } \\
\text { Echelon } \mathrm{II}^{\mathrm{a}}\end{array}$} & \multirow{3}{*}{$\begin{array}{c}\text { Mass } \\
\text { Standard }\end{array}$} & \multirow{3}{*}{$\begin{array}{c}1,200 \mathrm{~kg} \text { to } 1 \mathrm{mg} \\
2500 \mathrm{lb} \text { to } 0.001 \mathrm{lb} \\
8 \mathrm{oz} \text { to } 0.0125625\end{array}$} & $20 \mathrm{~kg}$ to $1 \mathrm{mg}$ & 2 year & 2 year \\
\hline & & & $1 \mathrm{~kg}$ to $1 \mathrm{mg}$ & & 4 year \\
\hline & & & $100 \mathrm{~g}$ to $1 \mathrm{mg}$ & & 4 year \\
\hline \multirow{4}{*}{$\begin{array}{c}\text { Mass } \\
\text { Echelon III }\end{array}$} & \multirow{3}{*}{$\begin{array}{c}\text { Mass } \\
\text { Standard }\end{array}$} & \multirow{3}{*}{$\begin{array}{c}2500 \mathrm{~kg} \text { to } 1 \mathrm{~g} \\
2500 \mathrm{lb} \text { to } 0.001 \mathrm{lb} \\
8 \mathrm{oz} \text { to } 0.0125625\end{array}$} & $\begin{array}{c}25 \mathrm{~kg}, 10 \mathrm{~kg} \text {, and } \\
5 \mathrm{~kg} \text { to } 100 \mathrm{mg}\end{array}$ & 2 year & 4 year \\
\hline & & & 200 kg, $500 \mathrm{lb}$ & & 4 year \\
\hline & & & $\begin{array}{l}25 \mathrm{~kg}, 10 \mathrm{~kg} \text {, } \\
\text { and } 1 \mathrm{~kg} \text { to } 1 \mathrm{mg} \\
50 \mathrm{lb}, 25 \mathrm{lb} \text {, and } \\
10 \mathrm{lb} \text { to } 0.001 \mathrm{lb}\end{array}$ & & 6 year \\
\hline & Weight Cart & $\leq 10000 \mathrm{lb}$ & Weight Cart & & 6 year \\
\hline \multirow{3}{*}{$\begin{array}{c}\text { Volume } \\
\text { Echelon I } \\
\text { (Gravimetric) }^{\mathrm{a}, \mathrm{b}}\end{array}$} & Prover & \multirow{3}{*}{$\begin{array}{l}500 \mathrm{~L} \text { to } 100 \mathrm{~mL} \\
100 \mathrm{gal} \text { to } 1 \mathrm{gal}\end{array}$} & 100 gal & 2 year & 4 year \\
\hline & Slicker & & 5 gal & & 4 year \\
\hline & Glassware & & $1 \mathrm{~L}, 1 \mathrm{qt}$ & & 6 year \\
\hline \multirow{3}{*}{$\begin{array}{l}\text { Volume } \\
\text { Echelon II } \\
\text { (Volume }^{\text {Transfer) }}{ }^{\text {a }}\end{array}$} & Prover & \multirow{3}{*}{$\begin{array}{l}5000 \mathrm{~L} \text { to } 100 \mathrm{~mL} \\
2000 \mathrm{gal} \text { to } 1 \mathrm{gal}\end{array}$} & 100 gal & 2 year & 2 year \\
\hline & LPG Prover & & 25 gal & & 6 year \\
\hline & $\begin{array}{c}\text { Test } \\
\text { Measure }\end{array}$ & & 5 gal & & 6 year \\
\hline \multirow{2}{*}{ Length $^{\mathrm{a}}$} & Tape & $\begin{array}{l}\text { Up to } 30 \mathrm{~m} \\
\text { Up to } 200 \mathrm{ft}\end{array}$ & $100 \mathrm{ft}$ & 2 year & 4 year \\
\hline & Rule & $\begin{array}{l}\text { Up to } 1 \mathrm{~m} \\
\text { Up to } 24 \mathrm{in}\end{array}$ & 18 in & & 4 year \\
\hline $\begin{array}{c}\text { Temperature } \\
\text { Accuracy Class } \\
\text { I, Class II, Class } \\
\text { III, and Class } \\
\text { IV }\end{array}$ & $\begin{array}{l}\text { Liquid-In- } \\
\text { Glass } \\
\text { Thermomete } \\
\text { rs, } \\
\text { RTD's, } \\
\text { SPRT's, } \\
\text { Thermistors, } \\
\text { and } \\
\text { Thermocoup } \\
\text { les } \\
\end{array}$ & $\begin{array}{l}230^{\circ} \mathrm{C} \text { to }-30^{\circ} \mathrm{C} \\
4500^{\circ} \mathrm{F} \text { to }-25^{\circ} \mathrm{F}\end{array}$ & $100{ }^{\circ} \mathrm{C}$ to $0^{\circ} \mathrm{C}$ & 4 year & 4 year \\
\hline Frequency $y^{\mathrm{a}, \mathrm{b}}$ & Tuning Fork & $10 \mathrm{kHz}$ to $1 \mathrm{kHz}$ & & 4 year & 4 year \\
\hline Time $^{\mathrm{a}, \mathrm{b}}$ & Stopwatch & $\leq 24 \mathrm{~h}$ & $3 \mathrm{~h}$ & 4 year & 4 year \\
\hline Hydrometer ${ }^{\mathrm{a}, \mathrm{b}}$ & Hydrometer & & & 4 year & 4 year \\
\hline $\begin{array}{c}\text { Grain } \\
\text { Moisture }^{\mathrm{b}, \mathrm{c}}\end{array}$ & $\begin{array}{c}\text { Grain } \\
\text { Sample }\end{array}$ & $\leq 20 \%$ & $\leq 20 \%$ & 4 year & 4 year \\
\hline
\end{tabular}




\begin{tabular}{|c|c|c|c|c|c|}
\hline $\begin{array}{c}\text { Measurement } \\
\text { Parameter }\end{array}$ & $\begin{array}{c}\text { Typical } \\
\text { Calibration } \\
\text { Standard }\end{array}$ & $\begin{array}{c}\text { Typical } \\
\text { Recognition } \\
\text { Scope Range }\end{array}$ & $\begin{array}{l}\text { Typical } \\
\text { PT Range }\end{array}$ & $\begin{array}{l}\text { Minimum } \\
\text { Recommended } \\
\text { Participation } \\
\text { per Parameter } \\
\text { (Alternating } \\
\text { Ranges) }\end{array}$ & Frequency \\
\hline \multicolumn{6}{|c|}{$\begin{array}{l}\text { NOTE: Mass Echelon I, II, and III correspond to details published in NIST Handbook 143, Program Handbook } \\
\text { and are directly related to OIML R111 (2004) classes of weights. Echelon I: } E_{1} \text { and } E_{2} \text {. Echelon II: } F_{1} \text { and } F_{2} \text {. } \\
\text { Echelon III: } \mathrm{M}_{1}, \mathrm{M}_{2}, \mathrm{M}_{3} \text { (etc.). The ASTM E617-13 classes correspond to those of OIML R111. NIST } \\
\text { Handbook } 105-1, \text { Class F weights corresponds to Echelon III. Volume Echelon I is related to gravimetric } \\
\text { volume calibration measurement procedures. Echelon II is related to volume transfer test methods. } \\
\text { Temperature Accuracy classes are related to guidance published in NVLAP 150-2 Annexes. }\end{array}$} \\
\hline
\end{tabular}

\section{Requirements}

The NIST OWM is not a formal accreditation body and does not enter into national or international agreements for acceptance and reciprocity. NIST OWM implements a Recognition Program (NIST HB 143, Program Handbook) for State Weights and Measures laboratories to ensure metrological traceability and ensure the implementation of uniform international measurement practices. NIST Handbook 143 is based on ISO/IEC 17025 and requires participation in a measurement assurance program and ongoing proficiency This policy and plan is designed to ensure State laboratories demonstrate competence and proficiency and comply with ISO/IEC 17025 and ILAC-P9.

\section{Policies}

\subsection{Compliance with International Standards}

It is NIST OWM policy to comply with ILAC policies and ISO/IEC 17043 when operating this proficiency testing program. OWM does not claim compliance to ISO/IEC 17011 and is not an accreditation body. Accreditation bodies that have signed the ILAC Mutual Recognition Arrangement (ILAC MRA) have been peer evaluated to ensure demonstrated compliance with ISO/IEC 17011 and ILAC-P9.

\subsection{Policy for PT Program Operations}

The NIST OWM offers IACET accredited training seminars in Fundamentals of Metrology, Mass, Volume, and Advanced Mass to State weights and measures laboratories and nonweights and measures participants. Courses participants are required to demonstrate successful achievement of learning objectives that are specifically related to competency. OWM also uses the results of PTs to evaluate the application of training concepts in participant State laboratories as Laboratory Auditing Program (LAP) problems. The LAP problems integrate PTs and serve as special internal technical audits. 
All recognized (NIST Handbook 143) laboratories shall demonstrate satisfactory participation in suitable PT activities that align with their measurement scope, where available. Failure to participate in an available PT will negatively impact recognition status and laboratory measurement scope limits. Proficiency tests and interlaboratory comparisons objectively validate laboratory measurement capability. NIST Handbook 143 requires the use of proficiency testing and interlaboratory comparisons as a mechanism to ensure measurement result quality and validate calibration methods

Laboratories shall report measurement uncertainties on calibration certificates for all PTs consistent with ISO/IEC Guide 98-1 (GUM).

Laboratories shall maintain records of PT participation, conduct follow-up evaluations, and demonstrate corrective action effectiveness when PT failures occur. Pass/fail criteria are determined and documented during the planning phase of each PT.

\subsection{Policy for Participation}

Any laboratory organization that would like their metrology personnel to participate in a PT activity within the scope of the program must agree to operate in accordance with these policies and conditions for participation.

- The participating organization shall regularly attend RMAP meetings and participate in PT/ILC planning discussions.

- Metrologists and their participating organizations shall be technically qualified for the measurement parameter of interest.

- OWM reserves the right to refuse participation to any organization or participant, even when they are technically qualified.

- OWM reserves the right to refuse participation to any organization or participant if the participant or participating organization has violated quality policies, procedures for artifact care and handling, repeated schedule delays, or other technical issues that could adversely affect the results for the other PT participants. When OWM identifies a policy or technical violation that negatively impacts the PT activity, each participating organization and their participants will be notified and provided technical guidance to ensure that the laboratory has an opportunity for corrective action.

- Each participating organization and metrologist shall follow all PT plan details and instructions, including the use of designated procedures.

- All OWM PTs are considered OPEN and anonymity is not implied or guaranteed. PT participants will not use any PT report for any purpose other than internal measurement assurance or accreditation/recognition activities. The use of OWM PTs in sales, marketing, or the advertising of the results of any participating laboratory are strictly prohibited.

- A PT participant will not falsify any measurement results or other information submitted to OWM.

- Each PT participant shall keep details regarding the activity in confidence. Seeking to obtain measurement information for artifacts prior to participation in the proficiency test is prohibited. Participants will only share data only with the PT coordinator, analyst, or 
OWM personnel. Sharing any artifact information or measurement results between participants, which is provided in the proficiency test final report, is prohibited. Exception: The PT coordinator, analyst, or OWM personnel may communicate draft $E_{n}$ values or significant error/bias to individual laboratories. This exception enables the PT coordinator, analyst, or OWM personnel to monitor immediate investigation, corrective action, and retesting (if needed) by the participant before the artifact is transferred to the next scheduled organization.

\subsection{Recognition Requirements}

A participant laboratory seeking initial OWM recognition (NIST Handbook 143), reinstating lapsed recognition, or maintaining ongoing recognition shall participate in the OWM PT Program. Laboratories initiating recognition must complete at least one approved PT aligned with each major parameter within the requested measurement scope before a Certificate of Measurement Traceability will be granted. Laboratories seeking ongoing recognition shall participate in at least one PT for each measurement area included in the laboratory's scope of recognition during a five-year period. Section 5 (PT Participation Plans) details these requirements.

Each laboratory shall develop a PT participation plan that will be coordinated with the appropriate RMAP region. The laboratory PT participation plan will be consistent with minimum PT Program participation guidelines. An example PT participation plan is available within this document. The laboratory shall annually review the PT participation plan and consider any operational changes, such as facility, personnel, equipment, standards, methods, measurement scope, or other factors.

Unique measurement parameters, artifacts, or methods may require special PT considerations. If a suitable PT is unavailable, an alternative approach may be considered by OWM. All PTs require OWM approval before commencing.

\subsection{Laboratory and Individual Metrologist Competence Status}

Laboratory recognition is contingent on successful PT participation. Each metrologist who has successfully performed within an OWM PT has demonstrated competence for that parameter. The laboratory organization must maintain at least one competent metrologist (authorized signatory) per measurement parameter within the recognized scope to achieve and retain recognition. Multiple authorized signatories within a measurement parameter are permitted and encouraged. Metrologists that do not successfully demonstrate competence through an OWM PT shall not be granted approved signatory status for the laboratory.

Laboratory management shall ensure that every personnel authorized to perform calibrations within the recognized measurement scope participate in each proficiency test when the artifact(s) arrives at the facility. This is an essential element of effective succession planning. Failing to comply with this requirement may impact the laboratory recognition status.

PT performance is not independent from laboratory processes. Each PT participant is evaluated 
in conjunction with the laboratory operational system (e.g., facility, equipment, standards, methods, etc.). When a metrologist performs measurements in another laboratory organization or facility, they shall demonstrate competence within that unique measurement system.

\section{PT Participation Plan}

The information presented below provides guidance for planning PT activities to meet the program policy requirements. The level of organization and frequency of PTs provided in this document is based on the following considerations and guiding principles.

a. PT plans and schedules shall be developed by each RMAP and updated at least annually so that PTs can be organized on a regional and/or national level. NIST OWM will participate in planning discussions and evaluate each specific plan for compliance program policies before authorizing the initiation of the activity. NIST OWM will develop and update an annual PT plan for programs that require national coordination.

b. Each RMAP region shall annually review PT Participation Plans to determine if the "frequency" is appropriate and adequate. A maximum number of PTs will be coordinated each year balancing between the full parameters/scopes of the laboratories and a reasonable PT workload. Coordination between RMAP regions is also acceptable to allow a new metrologist to participate in an PT within another region without having to wait an extended time period for the PT to be conducted in their region. Out of region participation requests will be documented within individual PT plans and approved by OWM before the activity is initiated.

c. The number of laboratories with the measurement capabilities for the specific metrology parameter will affect whether a PT is conducted regionally or nationally. For common measurement parameters, multiple RMAPs shall simultaneously organize PTs in the same measurement parameter to enable laboratories and metrologists to participate. For less common measurements, OWM will coordinate a PT on a national basis in order to adequate number of participants are available and organizations meet the PT requirement is fulfilled for this scope parameter.

d. Measurement Parameter. Preference will be given to measurement parameters with the largest workloads within the state laboratories. The number of measurements made within a specific measurement parameter will be considered. For example, mass calibrations make up nearly $90 \%$ and length calibration accounts for about $1 \%$ of the State Laboratory Program workload. Therefore, more PTs are required in mass than length. For this reason, a higher frequency than 2 years are required for some parameters. The historic stability of the standards used and tested within a specific metrology area shall be considered. Length standards in use within a laboratory have been shown to be more stable than mass standards. For this reason, fewer length PTs are required to provide adequate demonstration of measurement proficiency. 
e. Cost and Logistics. The long-range PT participation plan for participant laboratories, RMAPs and OWM shall include plans to develop PTs for each measurement parameter as it is economically and logistically feasible. The cost and logistics of the PT will be considered in selecting artifacts and in scheduling shipping. For example, large volume (e.g., 100 gal) or large mass (e.g., $500 \mathrm{lb}$ ) PTs that require the movement of a large trailer mounted prover through RMAP regions are coordinated and overseen by NIST. The frequency of this type of PT is also limited by cost of the standard because it is impractical to purchase multiple standards and the length of time necessary to circulate the standard to all laboratories within each region. In contrast, a 5 gallon test measure artifact is easily shipped at a modest cost. A large volume 100 gallon prover PT may be on a longer frequency (e.g., 5 year or 6 year) whereas small volume 5 gallon test measure, may be on a more frequent (e.g., 1 year or 3 year) schedule.

f. Minimum requirements. Each laboratory shall participate in one PT per major sub-area of their accredited or recognized scope every five years. It is recommended that organizations participate in PT activities for each specific measurement parameter and calibration method that the laboratory employs as a part of ongoing measurement assurance program. Failure to participate in an available PT will negatively impact accreditation/recognition and the approved measurement scope.

g. The specific ranges selected within each measurement parameter will be considered and should vary from PT to PT. For example, the range of $20 \mathrm{~kg}$ to $2 \mathrm{~kg}$ may be selected one year and the range $1 \mathrm{~kg}$ to $1 \mathrm{mg}$ may be selected in another. Single weights and/or sets may also be considered.

h. Additional Special PTs are permitted. Additional types of PT or Interlaboratory Comparison activities are permitted. Examples of special PT activities include the evaluation of: calibration of masses with unique densities or surface finishes, mass standard density or magnetism, , tests of environmental equipment used in buoyancy corrections (temperature, pressure, relative humidity), key comparisons, tests for new designs of field standards used in weights and measures, tests for evaluation of environmental effects on calibration values and uncertainties, tests for comparison of measurement procedures, tests for evaluation and verification of measurement traceability.

i. The OWM PT quality system procedures, forms, and tools are used to implement PT activities, including planning and reporting. Template PT follow-up tools include forms to help the laboratory document a successful PT as well as analyze and implement appropriate corrective action when unsuccessful PT results occur.

The sample matrix shown in Table 3 illustrates how a laboratory can document a proficiency testing strategy that will ensure each parameter within the accredited/recognized measurement 
scope is evaluated according to the requirements of this policy. Both the organization and accreditation/recognition body can observe at a glance all planned proficiency activities, confirming compliance to this policy or identifying gaps with ease.

Table 3. Sample PT Participation Plan.

\begin{tabular}{|c|c|c|c|c|c|c|c|c|c|c|}
\hline Parameter & 2018 & 2019 & 2020 & 2021 & 2022 & 2023 & 2024 & 2025 & 2026 & 2027 \\
\hline $\begin{array}{c}\text { Mass } \\
\text { Echelon I }\end{array}$ & & $\begin{array}{c}1 \mathrm{~kg} \\
\text { to } \\
1 \mathrm{mg} \\
4 \mathrm{yr}\end{array}$ & & $\begin{array}{c}20 \mathrm{~kg} \\
\text { to } \\
1 \mathrm{~kg} \\
4 \mathrm{yr}\end{array}$ & & $\begin{array}{c}1 \mathrm{~kg} \\
\text { to } \\
1 \mathrm{mg} \\
4 \mathrm{yr}\end{array}$ & & $\begin{array}{c}20 \mathrm{~kg} \\
\text { to } \\
1 \mathrm{~kg} \\
4 \mathrm{yr}\end{array}$ & & $\begin{array}{c}1 \mathrm{~kg} \\
\text { to } \\
1 \mathrm{mg} \\
4 \mathrm{yr}\end{array}$ \\
\hline $\begin{array}{c}\text { Mass } \\
\text { Echelon II }\end{array}$ & $\begin{array}{c}1 \mathrm{~kg} \\
\text { to } \\
1 \mathrm{mg} \\
4 \mathrm{yr}\end{array}$ & $\begin{array}{c}100 \mathrm{~g} \\
\text { to } \\
1 \mathrm{mg} \\
2 \mathrm{yr}\end{array}$ & $\begin{array}{c}20 \mathrm{~kg} \\
\text { to } \\
1 \mathrm{~kg} \\
4 \mathrm{yr}\end{array}$ & $\begin{array}{c}100 \mathrm{~g} \\
\text { to } \\
1 \mathrm{mg} \\
2 \mathrm{yr}\end{array}$ & $\begin{array}{c}1 \mathrm{~kg} \\
\text { to } \\
1 \mathrm{mg} \\
4 \mathrm{yr}\end{array}$ & $\begin{array}{c}100 \mathrm{~g} \\
\text { to } \\
1 \mathrm{mg} \\
2 \mathrm{yr}\end{array}$ & $\begin{array}{c}20 \mathrm{~kg} \\
\text { to } \\
1 \mathrm{~kg} \\
4 \mathrm{yr}\end{array}$ & $\begin{array}{c}100 \mathrm{~g} \\
\text { to } \\
1 \mathrm{mg} \\
2 \mathrm{yr}\end{array}$ & $\begin{array}{c}1 \mathrm{~kg} \\
\text { to } \\
1 \mathrm{mg} \\
4 \mathrm{yr}\end{array}$ & $\begin{array}{c}100 \mathrm{~g} \\
\text { to } \\
1 \mathrm{mg} \\
2 \mathrm{yr}\end{array}$ \\
\hline $\begin{array}{c}\text { Mass } \\
\text { Echelon III }\end{array}$ & $\begin{array}{c}25 \mathrm{~kg} \\
\text { to } \\
100 \mathrm{mg} \\
4 \mathrm{yr}\end{array}$ & $\begin{array}{c}500 \mathrm{lb} \\
6 \mathrm{yr}\end{array}$ & $\begin{array}{c}50 \mathrm{lb} \\
\text { to } \\
0.001 \mathrm{lb} \\
4 \mathrm{yr}\end{array}$ & $\begin{array}{l}\text { Weight } \\
\text { Cart } \\
6 \mathrm{yr}\end{array}$ & $\begin{array}{c}25 \mathrm{~kg} \\
\text { to } \\
100 \mathrm{mg} \\
4 \mathrm{yr}\end{array}$ & & $\begin{array}{c}50 \mathrm{lb} \\
\text { to } \\
0.001 \mathrm{lb} \\
4 \mathrm{yr}\end{array}$ & $\begin{array}{c}500 \mathrm{lb} \\
6 \mathrm{yr}\end{array}$ & $\begin{array}{c}25 \mathrm{~kg} \\
\text { to } \\
100 \mathrm{mg} \\
4 \mathrm{yr}\end{array}$ & $\begin{array}{c}\text { Weight } \\
\text { Cart } \\
6 \mathrm{yr}\end{array}$ \\
\hline $\begin{array}{l}\text { Volume } \\
\text { Echelon I }\end{array}$ & $\begin{array}{c}5 \text { gal } \\
\text { slicker } \\
4 \text { yr }\end{array}$ & $\begin{array}{c}100 \text { gal } \\
\text { prover } \\
6 \mathrm{yr}\end{array}$ & $\begin{array}{c}1 \mathrm{qt} \\
\text { glass } \\
4 \mathrm{yr}\end{array}$ & & $\begin{array}{c}5 \text { gal } \\
\text { slicker } \\
4 \text { yr }\end{array}$ & & $\begin{array}{c}1 \mathrm{qt} \\
\text { glass } \\
4 \mathrm{yr}\end{array}$ & $\begin{array}{c}100 \\
\text { gal } \\
\text { prover } \\
6 \mathrm{vr}\end{array}$ & $\begin{array}{c}5 \text { gal } \\
\text { slicker } \\
4 \text { yr }\end{array}$ & \\
\hline $\begin{array}{l}\text { Volume } \\
\text { Echelon II }\end{array}$ & $\begin{array}{c}5 \text { gal } \\
\text { test } \\
\text { measure } \\
2 \mathrm{yr}\end{array}$ & $\begin{array}{c}100 \text { gal } \\
\text { prover } \\
6 \mathrm{yr}\end{array}$ & $\begin{array}{c}5 \text { gal } \\
\text { test } \\
\text { measure } \\
2 \mathrm{yr}\end{array}$ & $\begin{array}{c}25 \mathrm{gal} \\
\mathrm{LPG} \\
6 \mathrm{yr}\end{array}$ & $\begin{array}{c}5 \text { gal } \\
\text { test } \\
\text { measure } \\
2 \mathrm{yr}\end{array}$ & & $\begin{array}{c}5 \text { gal } \\
\text { test } \\
\text { measure } \\
2 \mathrm{yr}\end{array}$ & $\begin{array}{c}100 \\
\text { gal } \\
\text { prover } \\
6 \mathrm{yr}\end{array}$ & $\begin{array}{c}5 \text { gal } \\
\text { test } \\
\text { measure } \\
2 \mathrm{yr}\end{array}$ & $\begin{array}{c}25 \text { gal } \\
\text { LPG } \\
6 \text { yr }\end{array}$ \\
\hline Length & & $\begin{array}{l}18 \mathrm{in} \\
\text { ruler } \\
4 \mathrm{yr}\end{array}$ & & $\begin{array}{c}100 \mathrm{ft} \\
\text { tape } \\
4 \mathrm{yr}\end{array}$ & & $\begin{array}{l}18 \mathrm{in} \\
\text { ruler } \\
4 \mathrm{yr}\end{array}$ & & $\begin{array}{c}100 \mathrm{ft} \\
\text { tape } \\
4 \mathrm{yr}\end{array}$ & & $\begin{array}{l}18 \mathrm{in} \\
\text { ruler } \\
4 \mathrm{yr}\end{array}$ \\
\hline $\begin{array}{l}\text { Temperature } \\
\text { All Echelons }\end{array}$ & & & $\begin{array}{c}\text { thermo- } \\
\text { meter } \\
4 \mathrm{yr}\end{array}$ & & & & $\begin{array}{c}\text { thermo- } \\
\text { meter } \\
4 \mathrm{yr}\end{array}$ & & & \\
\hline Frequency & $\begin{array}{c}\text { tuning } \\
\text { fork } \\
4 \mathrm{yr}\end{array}$ & & & & $\begin{array}{c}\text { tuning } \\
\text { fork } \\
4 \mathrm{yr}\end{array}$ & & & & $\begin{array}{c}\text { tuning } \\
\text { fork } \\
4 \mathrm{yr}\end{array}$ & \\
\hline Time & & $\begin{array}{l}\text { stop- } \\
\text { watch } \\
4 \mathrm{yr}\end{array}$ & & & & $\begin{array}{l}\text { stop- } \\
\text { watch } \\
4 \mathrm{yr}\end{array}$ & & & & $\begin{array}{c}\text { stop- } \\
\text { watch } \\
4 \mathrm{yr}\end{array}$ \\
\hline Hydrometers & & & $\begin{array}{c}\text { hydro- } \\
\text { meter } \\
4 \mathrm{yr}\end{array}$ & & & & $\begin{array}{c}\text { hydro- } \\
\text { meter } \\
4 \mathrm{yr}\end{array}$ & & & \\
\hline $\begin{array}{c}\text { Grain } \\
\text { Moisture }\end{array}$ & & $\begin{array}{c}\text { grain } \\
\text { moisture } \\
4 \mathrm{yr}\end{array}$ & & & & $\begin{array}{c}\text { grain } \\
\text { moisture } \\
4 \mathrm{yr}\end{array}$ & & & & $\begin{array}{c}\text { grain } \\
\text { moisture } \\
4 \mathrm{yr}\end{array}$ \\
\hline
\end{tabular}

